\title{
Subglacial tunnel valleys in the Alpine foreland: an example from Bern, Switzerland
}

\author{
Mirjam Dürst Stucki · Regina Reber • \\ Fritz Schlunegger
}

Received: 16 April 2010/ Accepted: 21 June 2010/Published online: 2 December 2010

(C) Swiss Geological Society 2010

\begin{abstract}
The morphology of the Alpine and adjacent landscapes is directly related to glacial erosion and associated sediment transport. Here we report the effects of glacio-hydrologic erosion on bedrock topography in the Swiss Plateau. Specifically, we identify the presence of subsurface valleys beneath the city of Bern and discuss their genesis. Stratigraphic investigations of more than 4,000 borehole data within a $430 \mathrm{~km}^{2}$-large area reveal the presence of a network of $>200 \mathrm{~m}$-deep and 1,000 m-wide valleys. They are flat floored with steep sided walls and are filled by Quaternary glacial deposits. The central valley beneath Bern is straight and oriented towards the NNW, with valley flanks more than $20^{\circ}$ steep. The valley bottom has an irregular undulating profile along the thalweg, with differences between sills and hollows higher than $50-100 \mathrm{~m}$ over a reach of $4 \mathrm{~km}$ length. Approximately $500 \mathrm{~m}$ high bedrock highlands flank the valley network. The highlands are dissected by up to $80 \mathrm{~m}$-deep and $500 \mathrm{~m}$-broad hanging valleys that currently drain away from the axis of the main valley. We interpret the valleys beneath the city of Bern to be a tunnel valley network which originated from subglacial erosion by melt water. The highland valleys served as proglacial meltwater paths and are hanging with respect to the trunk system, indicating that these incipient highland systems as well as the main gorge beneath Bern formed by glacial melt water under pressure.
\end{abstract}

Editorial handling: M. Fiebig.

M. Dürst Stucki $(\bowtie) \cdot$ R. Reber · F. Schlunegger

Institute of Geological Sciences, University of Bern,

Baltzerstrasse 1+3, 3012 Bern, Switzerland

e-mail: duerst@geo.unibe.ch
Keywords Tunnel valleys - Swiss Plateau - Quaternary · Unconsolidated sediments · Subglacial meltwater erosion

\section{Introduction}

Tunnel valleys are large elongated depressions of subglacial origin cut into bedrock (Mooers 1989; Sugden et al. 1991; Ó Cofaigh 1996; Sjogren et al. 2002; Götze et al. 2009). These features reach lengths of up to $100 \mathrm{~km}$ and widths of $4 \mathrm{~km}$ and often display asymmetric sides (Ó Cofaigh 1996; Jørgensen and Sandersen 2006). They exhibit undulating longitudinal profiles and contain sections that slope upwards (Jørgensen and Sandersen 2006). The depths of these features vary between 50 and $>400 \mathrm{~m}$ (Ó Cofaigh 1996). The cross-sectional morphologies are characterized by relatively steep sided valley flanks $\left(10^{\circ}-\right.$ $35^{\circ}$ ) and flat bottoms (Huuse and Lykke-Andersen 2000). Tunnel valleys occur as single features or as parts of dendritic or anastomosing patterns extending over areas of several square kilometers. They have been recognized in many areas formerly covered by Pleistocene ice sheets, including North America, north Germany, Denmark, Poland, the floor of the North Sea, Britain, Scotland and Ireland (Ehlers and Linke 1989; Eyles and McCabe 1989; Wingfield 1989; Huuse and Lykke-Andersen 2000). The sedimentary architecture of tunnel valley fills is characterized by a large variety of lithofacies including those associated with glacial, glaciofluvial or glaciolacustrine sedimentation, as well as those resulting from deposition under temperate (i.e., warm stage) conditions (Ó Cofaigh 1996). They are mostly filled with glacial sand, clay and till (BurVal Working Group 2006).

Tunnel valleys are interpreted to have served as subglacial drainage pathways for large volumes of melt water, 
and are thus considered to play a substantial role for the entire hydraulic system beneath glaciers (Jørgensen and Sandersen 2006). These valleys are formed by the interaction of several processes, dominated by subglacial erosion by water (Huuse and Lykke-Andersen 2000; Sjogren et al. 2002; Kirsch et al. 2006; Gabriel 2006). Tunnel valleys are also termed subglacial valleys, channels, linear incisions or major incisions (Mooers 1989; Ehlers and Wingfield 1991). Two main categories of erosional processes have been proposed: quarrying and abrasion of bedrock by suspended sediment particles in highly turbulent subglacial flows that operate as erosive tools (e.g., Benn and Evans 1998; Glasser and Bennett 2004). Direct glacial erosion (plucking and abrasion) is considered to have played an important, but secondary, role (Jørgensen and Sandersen 2006). In addition, the subglacial melt water erosion hypotheses suggested for tunnel valley formation can largely be divided into two proposals: (1) the progressive formation by a steady flow (e.g., Boulton and Hindmarsh 1987; Mooers 1989; Smed 1998; Huuse and Lykke-Andersen 2000; Praeg 2003), and (2) the sudden (near-synchronous) formation in response to catastrophic outbursts (jökulhlaup) of subglacially accumulated melt water (e.g., Wright 1973; Ehlers and Linke 1989; Brennand and Shaw 1994; Patterson 1994; Piotrowski 1994; Björnsson 1996; Clayton et al. 1999; Beaney 2002; Shaw 2002; Jørgensen and Sandersen 2006). Huuse and LykkeAndersen (2000) point out that it is not possible from the present data set to unravel the exact nature of the subglacial melt water erosion. Furthermore, variations in melt water discharge also play an important role in the development of glacial landforms (Eyles 2006; Salcher et al. 2009). Estimates of the volume/rate of melt water release, assessment of the character of the drainage pathways beneath continental ice sheets, and identification of processes leading to the formation of these features are still yet unresolved issues and have continued to be key scopes in Quaternary research (Lonergan et al. 2006).

The term tunnel valley is not unproblematic. Discussions on this topic mainly focus on the often missing, continuously descending thalweg along the valley and on the question whether or not this term implies a bank-full flow (Ehlers and Wingfield 1991). Authors who use the term tunnel channel anticipate that sills and hollows exist along the thalweg and that the subglacial water was flowing from bank to bank (Clayton et al. 1999; Sjogren et al. 2002). However, the term tunnel valley has been extensively used in the literature and is thus preferably applied for open and buried valleys of inferred subglacial origin (Jørgensen and Sandersen 2006).

The Swiss Plateau, on the northern side of the Alps, has been extensively covered by several hundreds of metersthick ice sheets during the Last Glacial Maximum (LGM)
(Bini et al. 2009) and earlier glaciations and is thus a prominent region for the occurrence of tunnel valleys (Fig. 1a). However, the Quaternary cover has precluded the precise allocation of these features. Spatial extents and orientations of tunnel valleys in the Swiss Plateau were unknown until groundwater surveys with drill holes were carried out (Schlüchter 1979). The main challenge has lain in the difficulty of restoring the geometry and spatial extents with sufficient details (Schlüchter 1979). This problem was overcome by extensive seismic campaigns and numerous drill holes during the past decades. Accordingly, Jordan $(2007,2008)$ produced the first maps of the bedrock surface over a large area covering nearly the whole Swiss Plateau at its northern margin between Neuchâtel and Konstanz (Fig. 1a). Similarly Schlüchter (1979, 1987) and Kellerhals and Isler (1983) identified erosional depressions in the region surrounding Bern, particularly in the Aare- and Gürbevalley south of Bern.

Here, we present new data regarding depth, width and orientation of the tunnel valley network beneath the city of Bern and discuss its origin (Fig. 1a). This area has been extensively explored by thousands of drill holes for geotechnical and geothermal purposes. In particular, the number of drill holes $>100 \mathrm{~m}$ deep has continuously increased during the past 15 years. This large dataset provides ideal conditions for restoring valley geometries with high spatial resolution. In addition, the region surrounding Bern has been a classical area for geological research with the result that (1) the architecture and stratigraphy of the bedrock is well established (Fig. 3a), (2) the spatial extent of glaciers of the Late Glacial Maximum (LGM) and earlier glaciations is know with sufficient detail, and that (3) minimum ages regarding the formation of the valley system beneath Bern can be discussed. We extract depth data of bedrock from ca. 30,000 drill holes (Fig. 3b) and compile published information regarding ages, geometries and spatial distribution of Quaternary deposits. The aim is to present a high-resolution reconstruction of the tunnel valley network beneath Bern together with an interpretation about the genesis of these features.

\section{Setting}

The bedrock of the Bern area (Fig. 3a) comprises Aquitanian to Langhian clastic deposits of the Molasse Basin. This basin is part of the peripheral foredeep flanking the Alpine orogen on its northern side, and formed in response to flexural accommodation of orogenic loading as the continent-continent collision between the Apulian microcontinent and the European plate proceeded (Pfiffner 1986; Pfiffner et al. 1997; Strunck and Matter 2002). The 

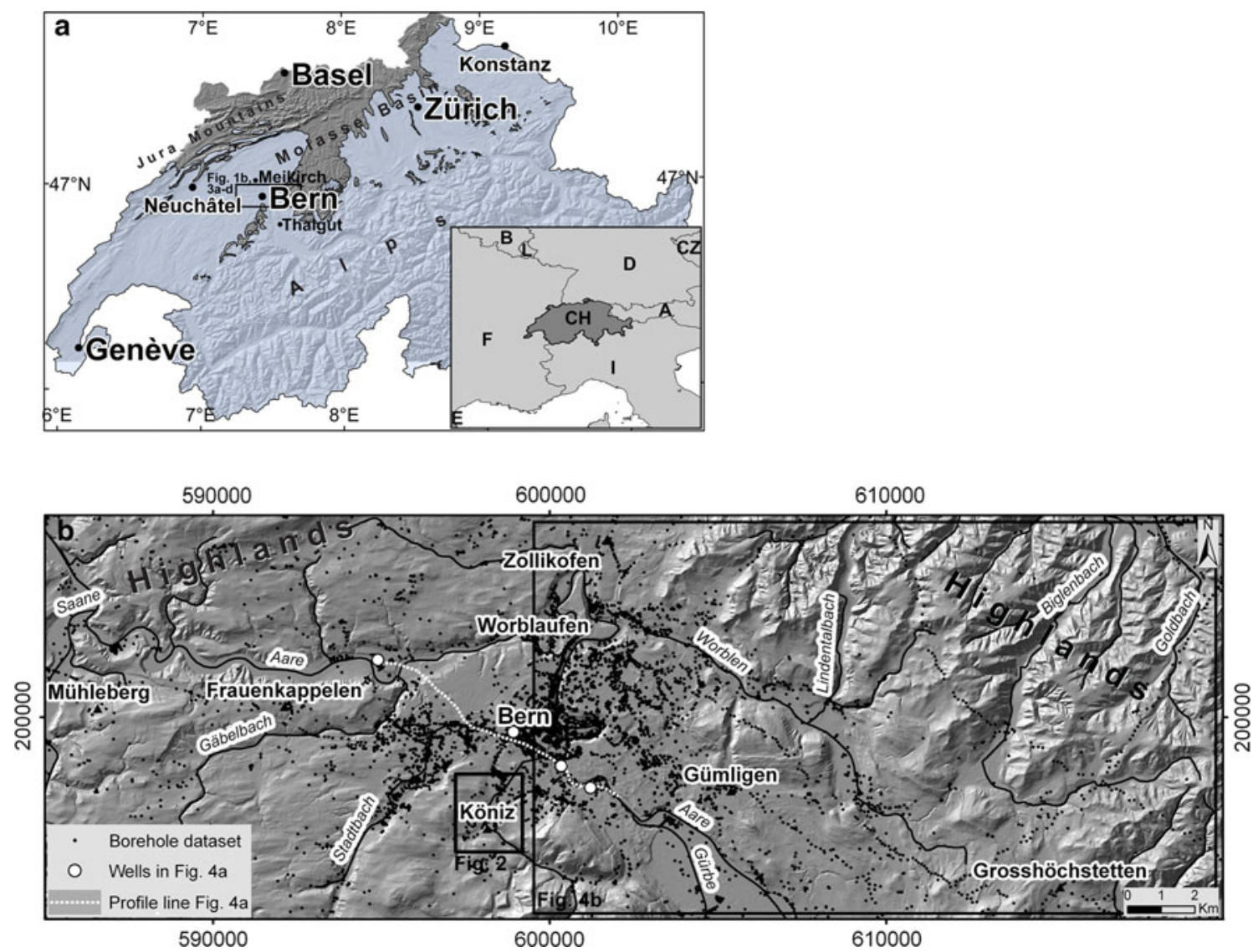

Fig. 1 a Local setting illustrating the location of the study area (black square) and the glaciation during LGM (light-coloured) (after Bini et al. 2009). b Study area with the modern drainage network and the initial borehole dataset (black dots)

Molasse Basin operated as a sedimentary sink for the erosional detritus of the Alps from the Oligocene to the Miocene (Homewood and Allen 1981). The basin fill can be characterized by two large-scale coarsening- and thickening-upward cycles (Matter et al. 1980; Strunck and Matter 2002) recording shifts from basin under to overfill (Sinclar et al. 1991; Schlunegger et al. 2007). The study area, on its northwestern side, is mainly underlain by the Aquitanian alternation of red to yellow mottled marls and massive sandstones beds of fluvial origin assigned to the Upper Freshwater Molasse group (Schlunegger et al. 1996). The southeastern sector of the Bern region comprises the glauconitic sandstone beds of the Burdigalian Upper Marine Molasse group. These deposits, characterized by a succession of massive bedded, parallel laminated and cross bedded sandstone beds, were deposited in a wave- and tidal-dominated shallow marine environment (Keller 1989). In the northeastern corner, a Langhian suite of fluvio-lacustrine conglomerates alternating with sandstones and mudstones forms the bedrock of the region.

During the Pleistocene, the Swiss Alps including the Plateau were repeatedly covered by glaciers of variable extent and thickness (Bini et al. 2009), with glacial erosion peaking at ca. 0.8-1.0 Ma particularly in the Alpine hinterland (Haeuselmann et al. 2007; Muttoni et al. 2003). The present-day morphology of the Alps and the foreland basin (Schlunegger and Hinderer 2003; Kelly et al. 2004; van der Beek and Bourbon 2008; Norton et al. 2010), including the region of Bern (Kellerhals et al. 1999; Isler 2005), is dominated by erosional and depositional features related to Quaternary glaciations. Preusser and Schlüchter (2004) concluded that there were probably more Pleistocene glaciations in the Alps than the four maximum glaciations proposed by Penck and Brückner (1901-1909). The Bern region was in the confluence area between the Rhône and Aare glaciers which left their fingerprints as gravel fields, moraines, drumlins and roches moutonées (Fig. 3a; Isler 2005).

The modern drainage network (Fig. 1b) is dominated by the Aare River that flows in a straight, NW-directed, ca. $20 \mathrm{~m}$-wide channel towards the city of Bern. In its historical center, the Aare switches towards the north and flows in tight, narrow and ca. $20 \mathrm{~m}$-deeply incised meanders before the river becomes re-directed towards the west. There it discharges in a west-oriented, ca. $100 \mathrm{~m}$ broad and gently meandering valley before leaving the study area. In 
the northeastern and eastern sectors of Fig. 1b, discharge occurs towards the northeast and is accomplished in $2 \mathrm{~m}$ wide channels which drain the densely dissected hilly landscape east of Bern. This region will be refer to as highlands in further sections of this paper.

\section{Methods}

Buried tunnel valleys have no clear topographic expression. In such cases, detailed studies of borehole logs, geophysical data and outcrops are needed to determine their morphology and extent. For the Bern area, more than 4,000 boreholes where used to restore depth, extent and orientation of bedrock depressions. In the following section, we describe the methodological steps including the preparation and selection of drill hole data, and the reconstruction of contour lines of bedrock. The ultimate goal of these steps is the detailed reconstruction of a map of bedrock elevation covering an area of $430 \mathrm{~km}^{2}$. All analytical steps were performed in a GIS environment.

\section{Data preparation and selection}

The region of the study area has been penetrated by more than 30,000 boreholes (Fig. 3b), the results of which are all documented in the database of the Amt für Wasser und Abfall, Bau-, Verkehrs und Energiedirektion, Kanton Bern. The borehole information is mainly based on cuttings, cores are sparse. This dataset was queried for information that is suitable for generating a rock surface map. Accordingly, the dataset was first split into drill holes that reached the bedrock and those where drilling ended in unconsolidated Quaternary deposits. From this latter dataset, we retain only the drill hole information that penetrated the subsurface by more than $20 \mathrm{~m}$ as control locations (Jordan 2007). Because these data reveal that the bedrock has not been reached at that particular depth, they contain qualitative information only and thus serve as general guidelines for the reconstruction of the bedrock surface map. Note that all drill holes penetrating into the Molasse bedrock were used for the reconstruction of this map. A selection of more drill holes with lower penetration depths will not change this picture (Dürst Stucki 2009; Reber 2009). In a second step, we removed boreholes with incorrect or ambiguous assignments regarding site location, lithologic architecture and the nature of sediment (i.e., bedrock or unconsolidated Quaternary deposit). The remaining 4,000 sites are thus characterized by precise information about the site location, and by a clear identification of the penetrated stratigraphic sequence (Molasse bedrock or Quaternary deposits). These drill logs were used in the subsequent analytical steps that are detailed below.
The boundary between Quaternary deposits and Molasse units is identified where well-cemented and consolidated sandstone beds and marls appear. We justify this approach because the amount of postdepositional erosion in the Molasse basin ranges between 1,000 and 2,000 $\mathrm{m}$ in the central part of the basin (e.g., Cederbom et al. 2004). Accordingly the Molasse bedrock is consolidated and wellcemented, whereas the Quaternary deposits appear as unconsolidated marls, gravels and sand. We therefore assign the unconsolidated sediments to the Quaternary.

\section{Reconstruction of contour lines of bedrock}

Contour lines of bedrock surface (e.g., Fig. 2) were reconstructed following the methodological approach detailed by Jordan $(2007,2008)$ who developed and tested the most suitable approach for this task. In particular, according to Jordan $(2007,2008)$, we considered (1) the boreholes that reached the bedrock surface, (2) the contour lines of the bedrock outcrops, (3) the boreholes that did not reach the bedrock surface, (4) and the inferred depth of the bedrock surface extracted from published geological profiles (e.g., Kellerhals and Isler 1983; Staeger 1988; Isler 2005). The contour lines were drawn by hand. We selected this approach because geostatistical analyses of the data

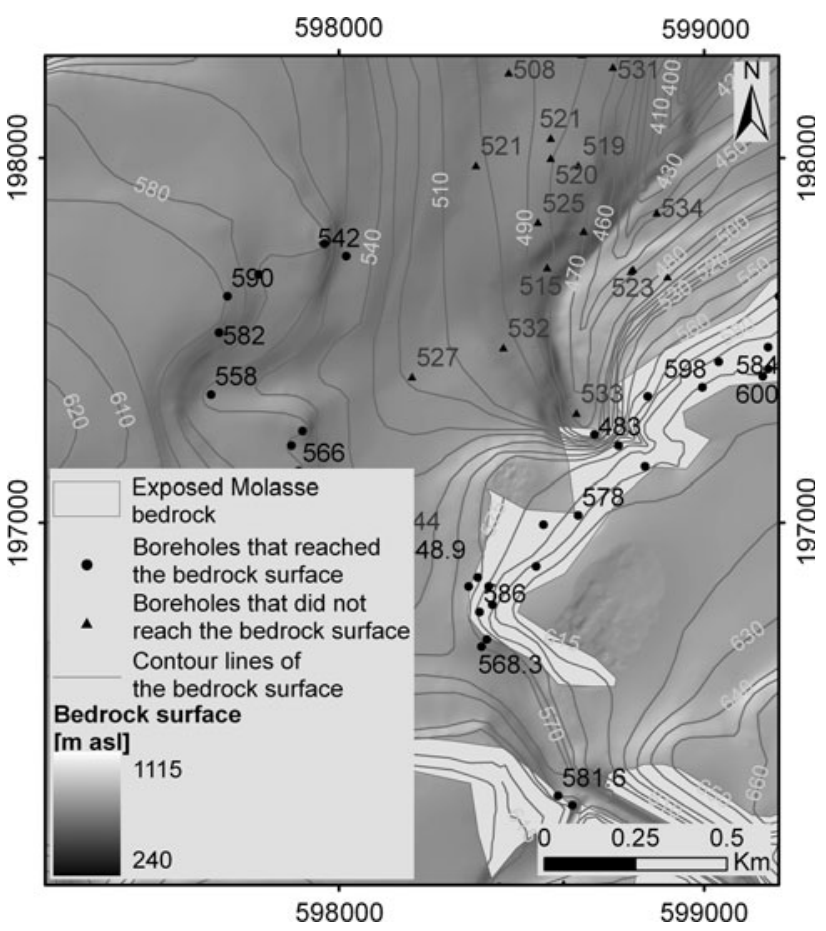

Fig. 2 Example of reconstructed contour lines of bedrock. The contour lines were drawn by hand considering the boreholes that reached the bedrock surface, the contour lines of the bedrock outcrops, the boreholes that did not reach the bedrock surface, and the derived depth of the bedrock surface extracted from published geological profiles 
yielded results that could not be reconciled with patterns of exposed bedrock (Dürst Stucki 2009). In order not to bias our interpretation with a predetermined geomorphological model, we linearly interpolated the contour lines where information from boreholes or exposed bedrock is sparse. We further improved the geometry of the contour lines by correcting deviations between restored bedrock map and available geological information. This was done by converting the contour lines into a $5 \mathrm{~m}$-resolution raster and by comparing the depth information of this raster with the borehole-data and sites of bedrock outcrops. Sites where the differences between the constructed bedrock topography and borehole/outcrop information exceeded $5 \mathrm{~m}$ were adjusted. The $5 \mathrm{~m}$ criterion is based on uncertainties in depth assignments of borehole data due to the mixing of cuttings as drilling proceeded. The resulting map was then compared to other maps of bedrock incisions in the Region of Bern produced by Pugin (1988), Staeger (1988) and Jordan $(2007,2010)$. The bedrock surface map is complementary to the reconstructed thickness pattern of unconsolidated sediment and is thus the difference between modern elevation and thickness of unconsolidated deposits.

We furthermore compiled the complete sedimentological record from four boreholes that penetrated the axes of the restored tunnel valleys. The purpose of this step was to reconstruct the lithologic architecture and to explore whether or not the tunnel valleys were formed and filled by subglacial meltwater. The sedimentological interpretation is, however, based solely on the cutting data and should thus to be treated with care. The well data also yield no age information. Accordingly, estimates of ages for the formation of the tunnel valleys and the accumulation of the Quaternary deposits rely on the temporal calibrations of the deposits at Meikirch and Thalgut, located approximately $10 \mathrm{~km}$ north and $15 \mathrm{~km}$ south of Bern, respectively (Fig. 1a).

\section{Results}

\section{Data density}

The restored contour lines of the bedrock surface is based on the highest density of drill hole data that is currently available for the Swiss Plateau. In particular, in the Bern area, the density of boreholes that reached the rock surface is 6.27 drill holes $/ \mathrm{km}^{2}$ (total 2,633), and the density of boreholes that did not reach the rock surface is 3.93 drill holes $/ \mathrm{km}^{2}$ (total 1,649). However, there is a clustering of information around the city of Bern, from where the data density decreases particularly towards the north and northeast (Fig. 3b). In addition, near the northeastern border of the study area, the Molasse bedrock is largely exposed and borehole information is sparse. The density of the data is therefore unevenly distributed and the map thus offers only a fractured picture of the buried tunnel valleys. Furthermore, only rough outlines of the buried valleys can be mapped from the borehole data, since the valleys are not penetrated entirely by the drill holes. Nevertheless, the available quality and density of data is sufficiently high to delineate a distinct picture of the Quaternary subsurface morphology that is described in the following paragraphs.

Thicknesses of unconsolidated deposits and erosion pattern

The map illustrating the thicknesses of the unconsolidated sediments (Fig. 3c) can be read as bedrock surface map (Fig. 3d) as both presentations are complementary. Indeed, thick accumulations of unconsolidated deposits imply deep incision into bedrock, particularly in the central part of the study area. However, accumulation of till might also result in thick accumulations of unconsolidated sediment. In this case, thicknesses of unconsolidated deposits do not necessarily correspond to depths of erosion. Despite these ambiguities, we note a distinct thickness pattern of Quaternary deposits and a corresponding picture of erosion that is characterized by (1) a SE-NW-oriented straight linear feature in the central region of the study area, (2) a linear SW-NE oriented depression in the southwestern sector, (3) anastomosing and linear features in the northern sector (Fig. 3d), and (4) and mainly elongate convex-up bedforms on the lateral sides (Fig. 3c).

The linear SE-NW-oriented element that is readily visible in the central part of the study area (labelled as A on Fig. 3d) is incised into the clastic rocks of the Lower Freshwater Molasse and Upper Marine Molasse groups. The orientation of this central incision corresponds to the ancient flow direction of the Aare glacier. The longitudinal profile is irregular with multiple lows and swells that differ in elevation by $50-100 \mathrm{~m}$. At one location the depth of the buried valley exceeds $250 \mathrm{~m}$. The central valley is generally more than $200 \mathrm{~m}$ deep and $1,000 \mathrm{~m}$ wide and has valley flanks that are more than $20^{\circ}$ steep. The precise allocation of the northwestern valley termination is difficult to determine due to a low data density. Here, we tentatively place its end at ca. 595,000/201,000 (Swiss coordinate system, CH1903) (A1 on Fig. 3d) as the available drill hole information in the region precludes an alternative solution (Fig. 3b). The termination of the central valley has a concave-up curvature, ascending from $<250 \mathrm{~m}$ a.s.l. to ca. $500 \mathrm{~m}$ a.s.l. over a distance of $1,500 \mathrm{~m}$ (Fig. $3 \mathrm{~d}$ ). The $\mathrm{W}$-directed, $100 \mathrm{~m}$-broad valley (B in Fig. 3d) is not considered as part of this incision as it lacks the characteristic swells and lows and displays multiple meanders. Interestingly, this central depression (A in Fig. 3d) is filled 

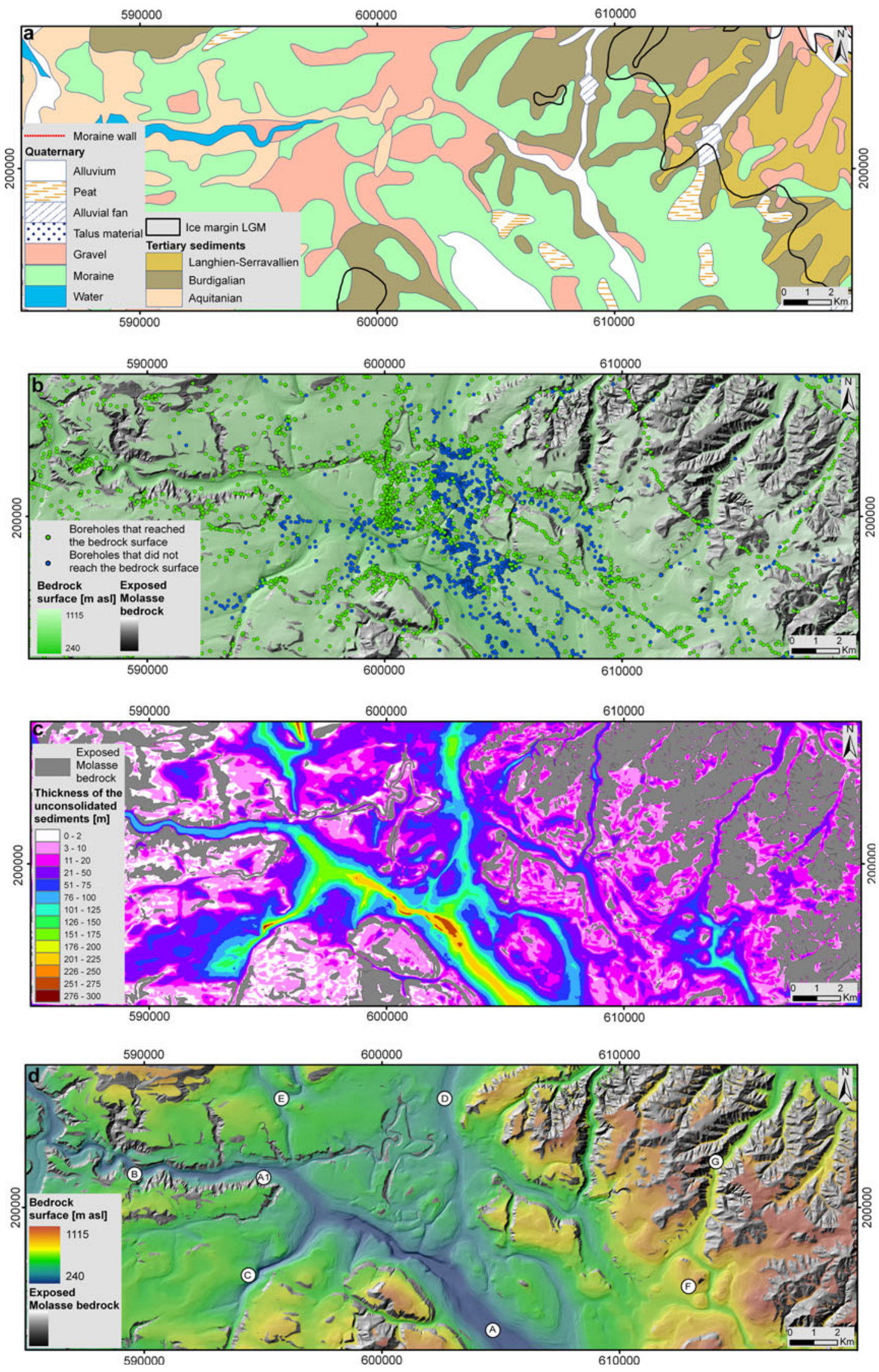
4 Fig. 3 a The geological framework of the study area and the ice margin during LGM (black line). b Boreholes used for restoring the subsurface map of bedrock. The green dots are boreholes which reached the bedrock surface at their endpoint, blue dots are drillings which ended in the unconsolidated sediments. $\mathbf{c}$ Thickness pattern of the unconsolidated sediments. This equals the difference between the topography of today and the reconstructed bedrock surface. d The reconstructed relief of bedrock surface. The coloured area represents the reconstructed bedrock surface in meter a.s.l. The grey shaded areas are locations where the Molasse bedrock is exposed at the surface

with a variety of Quaternary deposits comprising wellsorted sand, clay, silt, and a poorly sorted mixture of clays with gravel (Fig. 4a).

A second $>200 \mathrm{~m}$-deep and ca. $750 \mathrm{~m}$-wide linear feature is visible in the southwestern sector of the study area (labelled as $\mathrm{C}$ in Fig. 3d). It deepens from a few meters to $>200 \mathrm{~m}$, reaching an elevation of $<300 \mathrm{~m}$ a.s.l. at 594,000/198,000 (Swiss coordinate system, CH1903) (Fig. 3d), from where it ascends to a depth of $<100 \mathrm{~m}$ over a distance of $<1,000 \mathrm{~m}$. This erosional feature broadens to $>1,000 \mathrm{~m}$ as it joins the central valley in the middle sector of the study area, ca. $2 \mathrm{~km}$ west of the historical center of Bern. This second feature is oriented differently compared to the central valley, but parallels the flow direction of the Rhône glacier. A third linear erosional valley is detected in the central sector (labelled as $\mathrm{D}$ in Fig. 3d). It is $\mathrm{N}-\mathrm{S}$ oriented, ca. 100-150 m deep and hanging with respect to the central valley. It parallels the flow direction of the LGM and presumably earlier glaciers after the confluence of the Aare and Rhône glaciers. A further hanging erosional feature (labelled as E in Fig. 3d) is present farther west. It is up to $200 \mathrm{~m}$ deep, 200-400 m wide and splits into two branches. The assignment of a hanging character of these latter valleys with respect to the central depression can be challenged, but the available drill hole information preclude an alternative reconstruction.

In-between the erosional features, in the upland reaches, the terrain is characterized by the presence of isolated sediment accumulations forming bedforms with convex-up curvatures (Fig. 3c), particularly in the southeastern segment of the study area (labelled as F in Fig. 3d). These

Fig. 4 a The stratigraphy of wells that are based on cuttings and longitudinal section of the central valley (see Fig. 1b for location). The glacio-lacustrine environment in the cuttings does not fit to a glacio-fluvial regime beneath a glacier. The sedimentary deposits can therefore not be used to identify the processes controlling the incisions into the bedrock. b Schematic geomorphic model of subglacial tunnel valley and ascent of melt water underneath the glacier. The black arrows represent the proglacial meltwater pathways, the grey arrows indicate the melt water flow underneath the glacier towards the ice margin, and the light-coloured area represents the glaciations during LGM (after Bini et al. 2009) features are ca. 400-800 m long, $200 \mathrm{~m}$ wide and up to $150 \mathrm{~m}$ high. In addition, they are randomly grouped without a clear alignment, and they cover an area that is approximately $6-8 \mathrm{~km}^{2}$ large. Also in this sector, bedrock
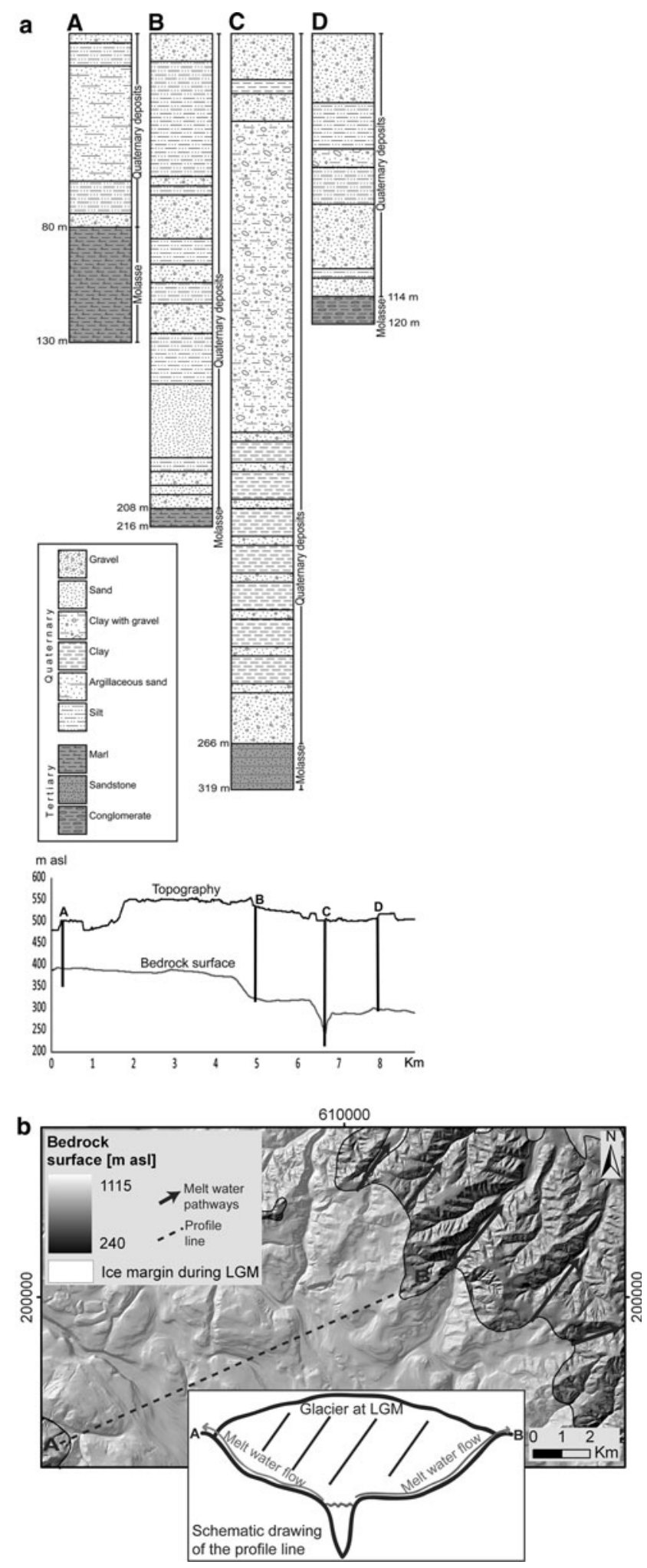
plateaus and ridges several square kilometers large form part of the upland.

The valley network is flanked by hilly highlands that reach elevations $>500 \mathrm{~m}$ higher than the valley axis (labeled as G in Fig. 3d). This is particularly the case in the northeastern part of the study area where bedrock ridges dissected by a network of steep fluvial channels shape the landscape. These highlands are cut by NE-directed valleys that are up to $500 \mathrm{~m}$ wide and that host tens of meters-thick fluvial gravels and floodplain mudstones. These highland valleys are hanging with respect to the main incision. At present, discharge in the upland valleys is oriented towards the northeast and is accomplished in ca. $2 \mathrm{~m}$-wide creeks.

\section{Interpretation and discussion}

Origin of tunnel valleys

Much controversy exists in the literature regarding the assignment of processes leading to the development of these erosional features, and a number of theories now exist in this context (Mooers 1989; Sugden et al. 1991; Ó Cofaigh 1996; Shaw 2002; Sjogren et al. 2002). The processes assigned for erosion comprise the range between direct glacial carving (plucking and abrasion) and dissected by turbulent subglacial melt water (Jørgensen and Sandersen 2006). This also concerns the erosional depression surrounding Bern (Kellerhals and Isler 1983) and the central and eastern Swiss Plateau (Jordan 2007, 2008) where the geometry of the depressions have been related to a subglacial environment. However, based on a recent compilation of processes in a subglacial environment, Burki (2009) noted that considerations of the importance of subglacial melt water on sediment budgets might have been underestimated in Switzerland.

Here, we interpret the valley network beneath Bern to display geometric features that have been considered assigned to tunnel valleys in the literature. In particularly, undulating profiles along the thalweg with irregular sills and hollows, straight valley courses together with concave up curvatures at their ends, as described above for the study area, are diagnostic features of tunnel valleys (e.g., Jørgensen and Sandersen 2006). Accordingly, we consider that subglacial melt water erosion exerted a dominant control on the formation of the erosional depressions beneath Bern. However, available data precludes the distinction between steady or catastrophic outburst flows as controlling process. Nevertheless, we can interpret with confidence that the valley network originated as the erosional power of the subglacial melt water was accelerated. In particular, the erosional potential of these drainages was enhanced by the overlying ice which increased the water pressure (see below). Indeed, the tunnel valleys in the centre and the southwestern sector have concave-up long profiles, which are diagnostic of confined subglacial flow. In addition, ascending flow of water up the valley axis to higher elevations (e.g., to the highlands) requires water to be under pressure (Fig. 4b). The combination of these observations thus indicates that the channels were eroded by pressurized, subglacial water (Sjogren et al. 2002).

The interpretation of an enhanced erosional potential for water flowing under an ice sheet, as interpreted above, is additionally supported by theoretical concepts. According to Shreve (1972), the subglacial water pressure is the sum of the ice overburden and the shear stress of the flowing water. Furthermore, the erosional potential is proportional to the total bed shear stress $\tau_{\text {tot }}$ and thus to the subglacial water pressure. Accordingly, erosion rates of overpressurised water equals:

$\tau_{\text {tot }}=\rho_{\mathrm{w}} g d+\rho_{\text {ice }} g h$

where $\rho_{\mathrm{w}}$ and $\rho_{\text {ice }}$ are the densities of ice and water, respectively, $d$ is water depth, $h$ is ice thickness, and $g$ is gravity (Shreve 1972; Sugden et al. 1991). It thus follows, that water overlain by ice with a thickness $h$ has a substantially higher erosional potential than water with a free upper surface. Because the thickness of the LGM ice sheet near Bern was estimated at approximately $500 \mathrm{~m}$ (Jäckli 1970; Kelly et al. 2004; Bini et al. 2009), erosion by melt water was most likely driven by pressure gradients below the glacier towards its margin. This leaded to subglacial erosional features in the underlying bedrock (Streif 2004; Jørgensen and Sandersen 2008; Stackebrandt 2009).

Also, as outlined above, we placed the end of the central valley where it switches towards the west (B in Fig. 3d), giving rise to a meandering, ca. $100 \mathrm{~m}$ broad, flat-floored depression. This allocation of the tunnel valley end is mainly based on geometric arguments as level valley floors and meandering geometries commonly form by subaerial water flow (e.g., Galloway and Hobday 1983; Whipple 2004). This meandering valley then most likely hosted the proglacial stream.

Location of tunnel valleys, and possible relationships to LGM and earlier glaciers

Figure $3 d$ suggests that the termination of the central tunnel valley has a concave-up curvature. As already mentioned above, this allocation of the valley end is rather vague as the low data density precludes a more precise reconstruction of the situation. Nevertheless, it is interesting to note that this area lies in the confluence region between the Aare and Rhône glaciers during the LGM and presumably earlier glaciations. It is likely that the 
confluence region offered preferred pathways for melt water to ascend to the highland and the proglacial valleys in the highlands east of Bern (see below). In addition, the different orientation of the tunnel valley in the southwestern sector ( $\mathrm{C}$ in Fig. 3d) asks for an ice flow that either originated in at the Alpine border, or that represented a branch of the Rhône glacier. We note, however, that the valley fill (Forst Schotter, Schlüchter in Naturaqua 1997; Isler 2005) comprises clast material with a petrographic composition that points to the hinterland of the Aare glacier (Schlüchter in Naturaqua 1997). We do not have a solution for what appears a contradiction between the origin of valley fill (i.e., Aare glacier) and inferred erosional agent (i.e., Rhône glacier). However, as discussed below, the sedimentology of the valley fill does not reflect the processes that carved the depressions. Most important, the oblique SW-NE orientation of this tunnel valley cannot be reconciled with the general NW-directed flow of the Aare glacier; it rather parallels the flow direction of the Rhône glacier.

Similar to the interpretation of the central depression, we consider the $\mathrm{N}$-directed, hanging erosional valleys in the central sector (D in Fig. 3d) to have been shaped by subglacial melt water as these valleys display swells and lows similar to the central depression, and as they are straight. It cannot be resolved why they are hanging with respect to the central depression. This feature most likely formed beneath the confluence of the Aare and Rhône glaciers. It is then possible that the ice flow was directed to the $\mathrm{N}$ after the confluence of these glaciers, which might explain the orientation of valley labeled as D in Fig. 3d. Furthermore, provided that the central and north-directed valleys were formed simultaneously, the hanging geometry implies that water had to ascend from deeper levels, which supports the interpretation of pressurized melt water.

Origin of upland and highland valleys

The highland valleys in the northeastern part of the study area ( $\mathrm{G}$ in Fig. 3d) reveal widths (up to $500 \mathrm{~m}$ ) that are too broad for the $<2 \mathrm{~m}$ wide creeks that flow inside. We interpret that these valleys operated as melt water pathways of proglacial streams where the proglacial water was flowing away from the ice margin towards the northeast (Fig. 4b). This melt water was either of supraglacial origin, or was derived from beneath the glacier. Alternatively, a combined origin is also possible. We cannot unequivocally solve this question but note that the NE-directed valley in the highlands have a SW-directed continuation to the inferred subglacial environment. This points to a contribution of subglacial origin. Accordingly, this interpretation corroborates the statement made above that the subglacial melt water was under pressure. Indeed, because the depth of the valley axis was at least $500 \mathrm{~m}$ below the elevation of the NE-directed highland valleys, water had to ascend from that depth to reach the ice margin bordering the highland valleys.

\section{Sedimentary fill of tunnel valleys}

The interpretation of erosional processes resulting in the formation of the tunnel valleys contrasts to the sedimentary fill of these features. In particular, the glacio-lacustrine environment inferred from mudstone cuttings (Fig. 4a) does not fit to a glacio-fluvial regime beneath a glacier. It appears that the sedimentary deposits in the tunnel valleys beneath Bern, and presumably also the erosional features described by Jordan $(2007,2008)$ in the eastern Swiss Plateau, cannot be used to identify the processes controlling the erosion of bedrock and resulting in the formation of the valley network. Lacustrine sediments might have accumulated at the time when the glaciers retreated far back to the Alpine hinterland, leaving behind a lake that was then filled during late glacial and interglacial time intervals (Van Husen 2000). Furthermore, the assumption that most of the sediments are not deposited by subglacial meltwater, points to a situation of subglacial meltwater streams rather incising that accumulating. It is likely that the melt water beneath ice was undersaturated with sediment, i.e. sediment load was presumably below the transport capacity of the melt water. The consequence is a high erosional potential (e.g., Tucker and Slingerland 1997), which provides further support for the inferred highly erosive power of the subglacial melt water.

Ages of the tunnel valleys

Tunnel valleys are often considered to be generated by several glaciations (Jørgensen and Sandersen 2006). It is likely that the sedimentary architecture of the valley fill as well as the surface morphology of the underlying bedrock are the combined result of erosion and accumulation over multiple cycles during several glaciations. Because the sedimentary fill of tunnel valleys comprises unconsolidated sediment with higher erodibility than the surrounding bedrock, the valleys are preferential locations for erosion during glacial periods (Jørgensen and Sandersen 2006). Although the sedimentary fill can be dated at some sites, the ages when the valleys were originally formed and maximum depths of incision were reached cannot be precisely determined. This is the case because (1) the time gap between the dated sedimentary fill and time of incision may be too large, and (2) the valleys and the valley fill deposits presumably record multiple phases of erosion and sediment accumulation (Jørgensen and Sandersen 2006), which precludes a unique age assignment. By dating the valley fill 
deposits, however, a minimum age for the time of valley erosion can be provided. Preusser et al. (2005) re-dated the well-studied Meikirch drilling site (located northwest of Bern, see Fig. 1a) and correlated the ages of these deposits with the ages of the sediments at the Thalgut drilling site (located south of Bern in the Aare valley, see Fig. 1a; Schlüchter 1987). With these age assignments, the lowest part of the Meikirch section is considered to have an age of isotope level (MIS) 7 (Preusser et al. 2005). This implies that bedrock dissection and deepening of the tunnel valley occurred at least ca. 250,000 years BP. Similarly, in the Alps were the glaciers were sourced, Haeuselmann et al. (2007) found that the major phase of glacial erosion occurred prior to the LGM. In summary, the question of when exactly the valleys were incised to their current depth will remain unresolved even if the oldest valley fill will be dated, mainly because the valley deposits infer processes of sediment accumulation (lakes, subglacial accumulation of ground moraines) that contrast to the highly turbulent flows inferred for the incision of the valleys. Most important, however, is the presumably multiphase origin of these features being formed during several ice ages (Schlüchter 1987). Similarly, multiple tunnel valleys generations are found elsewhere in northern Europe and are mostly attributed to the last three glaciations (Wingfield 1989; Piotrowski 1994; Dobracki and Krzyszkowski 1997; Glasser et al. 2004), which correspond to the possible incision time presented here.

\section{Conclusions}

The stratigraphic investigation of more than 4,000 borehole data within a $430 \mathrm{~km}^{2}$-large area allows for the first time the reconstruction of the details of a tunnel valley network beneath the city of Bern. The valleys are $>200$ m-deep, $1,000 \mathrm{~m}$ wide and have valley flanks more than $20^{\circ}$ steep. They are flat floored and filled by Quaternary glaciolacustrine deposits. The central valley beneath Bern is straight and oriented towards the NNW. The valley bottom has an irregular undulating profile along the thalweg, with differences between sills and hollows higher than 50-100 m over a reach of $4 \mathrm{~km}$ length. Other valleys farther east and the northeast reveal an anastomosing pattern of at least two branches. Approximately $500 \mathrm{~m}$ high bedrock highlands flank the valley network to the east. The highlands are dissected by up to $80 \mathrm{~m}$-deep and $500 \mathrm{~m}$ broad hanging valleys that currently drain away from the axis of the central valley. The network of tunnel valleys most likely originated from subglacial erosion by turbulent melt water. The downstream increase in the elevation of the valley axis indicates that these incipient highland systems as well as the central gorge beneath Bern formed by glacial melt water under pressure. Similarly, we relate efficient erosion, excavation of bedrock and the formation of the tunnel valley network with $>20^{\circ}$ steep shoulders to confined flow under pressure, caused by the overlying ice. The sedimentary fill of these valleys is characterized by sand, silts and clays. This implies that the sedimentary fill of the tunnel valleys beneath Bern, and presumably those in other regions of the Swiss Plateau, post-date incision and cannot be used to interpret and reconstruct the mechanisms leading to bedrock incision and valley deepening. Accordingly, any ages determined for the valley fill deposits postdate the origin of valley formation, which is, in the case for the Bern area, more than 250,000 years BP.

Acknowledgments This paper greatly benefited from scientific discussions with Christian Isenschmid, Peter Jordan, and Kevin Norton. Helpful suggestions by Christian Schlüchter improved the science of this paper. Dirk Rieke-Zapp is acknowledged for support in data processing and handling. The Amt für Wasser und Abfall, Bau-, Verkehrs und Energiedirektion, Kanton Bern provided the drill hole data, logistic support and the $2 \mathrm{~m}$ LIDAR DEM. The project was supported by the Swiss National Science foundation (SNF, 20TO21120525), and by the ESF TopoEurope project.

\section{References}

Beaney, C. L. (2002). Tunnel channels in southeast Alberta, Canada: Evidence for catastrophic channelized drainage. Quaternary International, 90, 67-74.

Benn, D. I., \& Evans, J. A. (1998). Glaciers \& Glaciations (p. 734). London: Arnold.

Bini, A., Buoncristiani, J.-F., Couterrand, S., Ellwanger, D., Felber, M., Florineth, D., Graf, H. R., Keller, O., Kelly, M., Schlüchter, C., \& Schoeneich, P. (2009). Die Schweiz während des letzteiszeitlichen Maximums (LGM) 1:500,000. Bundesamt für Landestopografie Swisstopo.

Björnsson, H. (1996). Scales and rates of glacial sediment removal: A $20 \mathrm{~km}$ long, $300 \mathrm{~m}$ deep trench created beneath Breidamerjökull during the Little Ice Age. Annales of Glaciology, 22, 141-146.

Boulton, G. S., \& Hindmarsh, R. C. A. (1987). Sediment deformation beneath glaciers: Rheology and geological consequences. Journal of Geophysical Research, 92, 9059-9082.

Brennand, T. A., \& Shaw, J. (1994). Tunnel channels and associated landforms, south-central Ontario: Their implications for icesheet hydrology. Canadian Journal of Earth Sciences, 31, $505-522$

Burki, V. (2009). Glaziale Erosion: Prozesse und ihre Kapazität. Nagra Arbeitsbericht NAB 09-06. Wettingen: Nagra.

BurVal Working Group. (2006). Buried Quaternary valleys-a geophysical approach. Zeitschrift der deutschen Gesellschaft für Geowissenschaften, 160, 237-247.

Cederbom, C., Sinclair, H., Schlunegger, F., \& Rahn, M. (2004). Climate induced rebound and exhumation of the European Alps. Geology, 32, 709-712.

Clayton, L., Attig, J. W., Mickelson, D. M. (1999). Tunnel channels formed in Wisconsin during the last glaciation. In D.M. Mickelson, \& J.W. Attig (Eds.), Glacial Processes Past and Present. Geological Society of America, Special Paper 337, 69-82.

Dobracki, R., \& Krzyszkowski, D. (1997). Sedimentation and erosion at the Weichselian ice-marginal zone near Golczewo, northwestern Poland. Quaternary Science Reviews, 16, 721-740. 
Dürst Stucki, M. (2009). Modellierung der Felsoberfläche in der Region Bern (Kartenblatt 1166, Bern 1:25,000). Unpublished Master's thesis, University of Bern, Switzerland.

Ehlers, J., \& Linke, G. (1989). The origin of deep buried channels of Elsterian age in northwest Germany. Journal of Quaternary Science, 4, 255-265.

Ehlers, J., \& Wingfield, R. (1991). The extension of the Late Weichselian/Late Devensian ice sheets in the North Sea Basin. Journal of Quaternary Science, 6, 313-326.

Eyles, N. (2006). The role of meltwater in glacial processes. Sedimentary Geology, 190, 257-268.

Eyles, N., \& McCabe, A. M. (1989). Glaciomarine facies within subglacial tunnel valleys-the sedimentary record of Glacioisostatic down-wrapping in the Irish Sea Basin. Sedimentology, 36, $431-448$

Gabriel, G. (2006). Gravity investigation of buried Pleistocene subglacial valleys. Near Surface Geophysics, 4, 321-332.

Galloway, W. E., \& Hobday, D. K. (1983). Terrigenous clastic depositional systems (p. 423). New York: Springer.

Glasser, N. F., \& Bennett, M. R. (2004). Glacial erosional landforms: origins and significance for palaeoglaciology. Progress in Physical Geography, 28, 43-75.

Glasser, N. F., Etienne, J. L., Hambrey, M. J., Davies, J. R., Waters, R. A., \& Wilby, P. R. (2004). Glacial meltwater erosion and sedimentation as evidence for multiple glaciations in west Wales. Boreas, 33, 224-237.

Götze, H.-J., Gabriel, G., Giszas, V., Hese, F., Kirsch, R., Köther, N., et al. (2009). The ice age paleo-channel "Ellerbeker Rinne"-an integrated 3D gravity study. Zeitschrift der deutschen Gesellschaft für Geowissenschaften, 160, 279-294.

Haeuselmann, P., Granger, D. E., Jeannin, P. Y., \& Lauritzen, S. E. (2007). Abrupt glacial valley incision at $0.8 \mathrm{Ma}$ dated from cave deposits in Switzerland. Geology, 35, 143-146.

Homewood, P., \& Allen, P. (1981). Wave-, tide- and currentcontrolled sandbodies of Miocene Molasse, Western Switzerland. Bulletin of the American Association of Petroleum Geologists, 65, 2534-2545.

Huuse, M., \& Lykke-Andersen, H. (2000). Overdeepened Quaternary valleys in the eastern Danish North Sea: Morphology and origin. Quaternary Science Reviews, 19, 1233-1253.

Isler, A. (2005). Erläuterungen zum geologischen Atlas der Schweiz 1:25,000, Blatt Bern 1166. Bundesamt für Wasser und Geologie.

Jäckli, A. (1970). Die Schweiz zur letzten Eiszeit: Atlas der Schweiz 6. Wabern-Bern: Eidgenössische Landestopographie.

Jordan, P. (2007). Digitales Höhenmodell der Basis des Quartärs (DHM B_QU, "Felsmodell"). NAGRA NAB 07-12.

Jordan, P. (2008). Digitales Höhenmodell. Am Beispiel der Felsoberfläche der Nordschweiz. Gas-Wasser-Abwasser, 6, 443-449.

Jordan, P. (2010). Analysis of overdeepened valley using the digital elevation model of bedrock surface of northern Switzerland. Swiss Journal of Geosciences (in press).

Jørgensen, F., \& Sandersen, P. B. E. (2006). Buried and open tunnel valleys in Denmark-erosion beneath multiple ice sheets. Quaternary Science Reviews, 25, 1339-1363.

Jørgensen, F., \& Sandersen, P. B. E. (2008). Mapping of buried tunnel valleys in Denmark: New perspectives for the interpretation of the Quaternary succession. Geological Survey of Denmark and Greenland Bulletin, 15, 33-36.

Keller, B. (1989). Fazies und Stratigraphie der Oberen Meeresmolasse (Unteres Miozän) zwischen Napf und Bodensee. Unpublished $\mathrm{PhD}$ thesis, University of Bern, Bern, $402 \mathrm{pp}$.

Kellerhals, P., Haefeli, C. \& Rutsch, R.F. (1999). Blatt 1167 Worb. Geol. Atlas Schweiz 1:25,000. Karte 104 mit Erläuterungen. Bundesamt für Landestopografie Swisstopo.
Kellerhals, P., \& Isler, A. (1983). Profilserie durch die Quartärfüllung des Aare- und Gürbetroges zwischen Thunersee und Bern. Eclogae Geologicae Helvetiae, 76, 417-430.

Kelly, M. A., Buoncristiani, J. F., \& Schlüchter, C. (2004). A reconstruction of the last glacial maximum (LGM) ice-surface geometry in the western Swiss Alps and contiguous Alpine regions in Italy and France. Eclogae Geologicae Helvetiae, 97, $57-75$.

Kirsch, R., Rumpel, H.-M., Scheer, W., \& Wiederhold, H. (2006). Groundwater Resources in Buried Valleys: A Challenge for Geosciences: Hannover (p. 303). Germany: Leibniz Institute for Applied Geosciences (CGA-Institut).

Lonergan, L., Maidment, S., \& Collier, J. (2006). Pleistocene subglacial tunnel valleys in the central North Sea basin: 3-D morphology and evolution. Journal of Quaternary Sciences, 21, 891-903.

Matter, A., Homewood, P., Caron, C., Rigassi, D., Van Stujivenberg, J., Weidmann, M., et al. (1980). Flysch and molasse of western and central Switzerland. In R. Trümpy (Ed.), Geology of Switzerland, A Guidebook, Part B, Excursions (pp. 261-293). Basel: Schweizerische Geologische Kommission, Wepf.

Mooers, H. D. (1989). On the Formation of the Tunnel Valleys of the Superior Lobe, Central Minnesota. Quaternary Research, 32, 24-35.

Muttoni, G., Carcano, C., Garzanti, E., Ghielmi, M., Piccin, A., Pini, R., et al. (2003). Onset of major Pleistocene glaciations in the Alps. Geology, 31, 989-992.

Naturaqua (1997). Hydrologie der Region westlich und nordwestlich von Bern. Wasser- und Energiewirtschaftsamt des Kantons Bern (WEA).

Norton, K., Abbühl, L. \& Schlunegger, F. (2010). Glacial conditioning as an erosional driving force in the Central Alps. Geology, $38,655-658$.

Ó Cofaigh, C. (1996). Tunnel valley genesis. Progress in Physical Geography, 20, 1-19.

Patterson, C. J. (1994). Tunnel-valley fans of the St. Croix moraine, eastcentral Minnesota, USA. In W. P. Warren \& D. G. Croot (Eds.), Formation and Deformation of Glacial Deposits (pp. 69-87). Rotterdam: Balkema.

Penck, A., \& Brückner, E. (1901-1909). Die Alpen im Eiszeitalter (3 Bände). Tachnitz, Leipzig.

Pfiffner, O. A. (1986). Evolution of the north Alpine foreland basin in the central Alps. In P.A. Allen, \& P. Homewood (Eds.), Foreland Basins. International Association of Sedimentologists, Special Publication 8, 219-228.

Pfiffner, O. A., Erard, P. F., \& Stäuble, M. (1997). Two cross sections through the Swiss Molasse basin. In O. A. Pfiffner, P. Lehner, P. Heitzmann, S. Müller, \& A. Steck (Eds.), Deep Structure of the Swiss Alps: Results From the National Research Program 20 (NRP 20) (pp. 64-72). Basel: Schweizerische Geologische Kommission, Birkhäuser.

Piotrowski, J. A. (1994). Tunnel-valley formation in Northwest Germany-geology, mechanisms of formation and subglacial bed conditions for the bornhoved tunnel valley. Sedimentary Geology, 89, 107-141.

Praeg, D. (2003). Seismic imaging of mid-Pleistocene tunnel-valleys in the North Sea Basin-high resolution from low frequencies. Journal of Applied Geophysics, 53, 273-298.

Preusser, F., Drescher-Schneider, R., Fiebig, M., \& Schlüchter, C. (2005). Reinterpretation of the Meikirch pollen record, Swiss Alpine Foreland, and implications for Middle Pleistocene chronostratigraphy. Journal of Quaternary Science, 20, 607-620.

Preusser, F., \& Schlüchter, C. (2004). Dates from an important early Late Pleistocene ice advance in the Aare valley, Switzerland. Eclogae Geologicae Helvetiae, 97, 245-253. 
Pugin A. (1988). Carte des isohypses de la base des sédiments du Quarternaire en Suisse occidentale, avec quelques commentaires. Landeshydrologie und -geologie Bern. Geologische Berichte Nr. 3.

Reber, R. (2009). Modellierung der Felsoberfläche in der Region Bern (Kartenblatt 1167, Worb 1:25,000). Unpublished Master's thesis, University of Bern, Switzerland.

Salcher, B. C., Hinsch, R., \& Wagreich, C. (2009). High-resolution mapping of glacial landforms in the North Alpine Foreland, Austria. Geomorphology, 122, 283-293.

Schlüchter, C. (1979). Übertiefte Talabschnitte in Berner Mittelland zwischen Alpen und Jura (Schweiz). Eiszeitalter und Gegenwart, 29, 101-113.

Schlüchter, C. (1987). Talgenese im Quartär-eine Standortbestimmung. Geographica Helvetica, 2, 109-115.

Schlunegger, F., Burbank, D. W., Matter, A., Engesser, B., \& Mödden, C. (1996). Magnetostratigraphic calibration of the Oligocene to Middle Miocene (30-15 Ma) mammal biozones and depositional sequences of the Swiss Molasse Basin. Eclogae Geologicae Helvetiae, 89, 753-788.

Schlunegger, F., \& Hinderer, M. (2003). Pleistocene/Holocene climate change, re-establishment of fluvial drainage network and increase in relief in the Swiss Alps. Terra Nova, 15, 88-95.

Schlunegger, F., Rieke-Zapp, D., \& Ramseyer, K. (2007). Possible environmental effects on the evolution of the Alps-Molasse Basin system. Swiss Journal of Geosciences, 100, 383-405.

Shaw, J. (2002). The meltwater hypothesis for subglacial bedforms. Quaternary International, 90, 5-22.

Shreve, R. L. (1972). Movement of water in glaciers. Journal of Glaciology, 11(62), 205-214.

Sinclar, H. D., Coakley, B. J., Allen, P. A., \& Watts, A. B. (1991). Simulation of foreland basin stratigraphy using a diffusion model of mountain belt uplift and erosion: an example from the central Alps, Switzerland. Tectonics, 10, 599-620.

Sjogren, D. B., Fisher, T. G., Taylor, L. D., Jol, H. M., \& MunroStasiuk, M. J. (2002). Insipient tunnel channels. Quaternary International, 90, 41-56.
Smed, P. (1998). Die Entstehung der dänischen und norddeutschen Rinnentäler (Tunneltäler)—Glaziologische Gesichtspunkte. Eiszeitalter und Gegenwart, 48, 1-18.

Stackebrandt, W. (2009). Subglacial channels of Northern Germany-a brief review. Zeitschrift der deutschen Gesellschaft für Geowissenschaften, 160, 203-210.

Staeger, D. (1988) Baugrundkarte der Stadt Bern und Umgebung 1:10,000 mit Erläuterungen. Beiträge zur Geologie der Schweiz, kleine Mitteilung Nr. 80.

Streif, H. (2004). Sedimentary record of Pleistocene and Holocene marine inundations along the North Sea coast of Lower Saxony, Germany. Quaternary International, 112, 3-28.

Strunck, P., \& Matter, A. (2002). Depositional evolution of the Western Swiss Molasse. Eclogae Geologicae Helvetiae, 95, 197-222.

Sugden, D. W., Denton, G. H., \& Marchant, D. (1991). Subglacial meltwater channel systems and ice sheet overriding, Asgard Range, Antartica. Geogafiska Annaler, 73A, 109-121.

Tucker, G. E., \& Slingerland, R. (1997). Drainage basin response to climate change. Water Resources Research, 33, 2031-2047.

Van der Beek, P., \& Bourbon, P. (2008). A quantification of the glacial imprint on relief development in the French western Alps. Geomorphology 97, 52-72. Earth and Planetary Science Letters, Annual Reviews, 32, 151-185.

Van Husen, D. (2000). Geological processes during the Quaternary. Mitteilungen der Österreichischen Geologischen Gesellschaft, 92, 135-156.

Whipple, K. X. (2004). Bedrock Rivers and the geomorphology of active orogens. Annual Reviews Earth and Planetary Science, $32,151-185$.

Wingfield, R. T. R. (1989). Glacial incisions indicating middle and upper Pleistocene ice limits of Britain. Terra Nova, 1, 538-548.

Wright, H.E. (1973). Tunnel valleys, Glacial surges, and subglacial hydrology of the superior lobe, Minnesota. In R.F. Black, R.P. Goldthwait, \& H.B. Willman, (Eds.), The Geological Society of America, Memoir 136, 251-276. 